\title{
PENGARUH MULTIMEDIA INTERAKTIF BERBASIS MICROSOFT POWER POINT TERHADAP HASIL BELAJAR SISWA KELAS VIII MTs NURUL FALAH NW LAJUT TAHUN PELAJARAN 2019/2020
}

\author{
Maya Ekaningtias ${ }^{1)}$, Nunung Safilin ${ }^{2)}$ \\ Program Studi Pendidikan Biologi FKIP UNW Mataram \\ E-mail: mentias4life@gmail.com
}

\begin{abstract}
Abstrak. Tujuan penelitian ini untuk mengetahui pengaruh multimedia interaktif berbasis Microsoft PowerPoint terhadap hasil belajar siswa kelas VIII MTs Nurul Falah NW Lajut tahun pelajaran 2019/2020. Jenis penelitian ini ialah quase experiment dengan Pre-test Post-test Control Group Design. Populasi dalam penelitian ini adalah seluruh siswa kelas VIII MTs Nurul Falah NW Lajut tahun pelajaran 2019/2020. Sampelnya adalah siswa kelas VIII yang berjumlah 50 orang dan terbagi menjadi 2 kelas, kelas VIII B berjumlah 25 orang sebagai kelas eksperimen dan kelas VIII A yang berjumlah 25 orang sebagai kelas kontrol.. Variabel bebas dalam penelitian ini adalah penerapan media Microsoft power point sedangkan variabel terikat adalah hasil belajar. Berdasarkan hasil penelitian, nilai rata-rata hasil belajar siswa dengan penerapan media Microsoft power point sebesar 79,92 sedangkan dengan metode konvensional sebesar 69,56. Berdasarkan uji hipotesis dengan menggunakan uji $\mathrm{t}$ yaitu $\mathrm{t}_{\text {hitung }}=3,147>\mathrm{t}_{\text {tabel }}=1,677$. Dengan demikian, dari hasil penelitian dapat disimpulkan bahwa penerapan media Microsoft power point menunjukkan pengaruh yang signifikan dengan peningkatan hasil belajar siswa kelas VIII MTs Nurul Falah NW Lajut tahun pelajaran 2019/2020.
\end{abstract}

Kata kunci: Multimedia interaktif berbasis Microsoft PowerPoint, Hasil Belajar.

Abstract. The purpose of the study was to determine the effect of the Microsoft PowerPointbased interactive multimedia model on learning outcomes of Class VIII students of the MTs Nurul Falah NW Lajut 2019/2020 school year. This type of research is quasi-experimental. The research design used was a pre-test post-test control group design. The population in this study were all students of class VIII MTs Nurul Falah NW Lajut in Academic Year of 2019/2020. The samples were all students of VIIIth grade in amounts of 50 students which had been divided into 2 classes. VIII B class amounting to 25 people as an experimental class while VIII A class, amounting to 25 students as a control class. The independent variable in this study was the application of the Microsoft PowerPoint-based interactive multimedia model while the dependent variable was the learning outcomes. Based on the results of the study, the average value of students' learning outcomes with the application of the Microsoft PowerPoint-based interactive multimedia model of 79,92 while with the conventional method of 69,56 . Based on the hypothesis test using the t test that is $t_{\text {count }}=3,147>t_{\text {table }}=1,677$. Thus, from the results of the study above, it can be concluded that the learning model of Microsoft PowerPoint-based interactive multimedia has a significant effect on learning outcomes of students of class VIII of MTs Nurul Falah NW Lajut 2019/2020 school year.

Keywords: Interactive multimedia based on Microsoft PowerPoint, Learning Outcomes.

\section{PENDAHULUAN}

Pendidikan merupakan usaha sadar yang dilakukan melalui proses bimbingan, latihan, dan pengajaran yang bertujuan mengantarkan para siswa menuju pada perubahan-perubahan tingkah laku (Mulyasa,
2012 :4). Perkembangan pendidikan harus dilakukan untuk meningkatkan kualitas suatu bangsa. Pembelajaran IPA khususnya Biologi di setiap sekolah selalu mengalami titik jenuh bagi semua siswa, di samping banyaknya nama-nama ilmiah yang harus dihapalkan 
siswa juga selalu mendapatkan suasana belajar yang membosankan. Oleh karena itu, pelajaran IPA harus dibuat lebih menarik menggunakan media yang tepat supaya materi yang disampaikan mudah dipahami, karena IPA lebih membutuhkan pemahaman. Pemakaian media pembelajaran dalam proses belajar mengajar dapat membangkitkan keinginan dan minat baru, membangkitkan motivasi dan rangsangan kegiatan belajar, dan membawa pengaruh-pengaruh psikologis terhadap siswa (Hamalik (1986) dalam Arsyad (2011: 15). Menurut Sudjana (2014:46), hasil belajar merupakan kemampuan yang dimiliki oleh siswa setelah menerima pengalaman belajar. Hasil belajar merupakan pembelajaran sesuai dengan kemampuan yang dimilikinya.

$$
\text { Menurut Susilana (2009:126), }
$$

penggunaan multimedia interaktif dalam pembelajaran bertujuan untuk mempermudah dan memperjelas penyajian pesan agar tidak terlalu bersifat verbalistis, mengatasi keterbatasan waktu, ruang, dan daya indera para siswa, dapat digunakan secara tepat dan bervariasi, seperti: meningkatkan motivasi dan gairah belajar para siswa untuk menguasai materi pelajaran, mengembangkan kemampuan siswa dalam berinteraksi langsung dengan lingkungan dan sumber belajar lainnya terutama bahan ajar yang berbasis ICT dan memungkinkan bagi siswa untuk mengukur atau mengevaluasi sendiri hasil belajarnya. Multimedia interaktif yang digunakan pada penelitian ini adalah Microsoft PowerPoint.

Berdasarkan hasil observasi yang dilakukan di MTs Nurul Falah NW Lajut, peneliti menemukan suatu permasalahan yang ada yaitu sebagian besar guru belum menerapkan media pembelajaran berupa MMI seperti Microsoft Power Point sedangkan di sekolah sudah tersedia LCD dan laptop, akan tetapi guru belum memaksimalkan penggunaan fasilitas yang telah disediakan dan guru masih terpaku menggunakan media pembelajaran seperti buku bacaan, LKS, modul dan lain-lain, akibatnya peserta didik kurang tertarik dalam menyimak dan memperhatikan materi ketika proses pembelajaran berlangsung. Tujuan penelitian ini adalah untuk mengetahui pengaruh Multimedia Interaktif Berbasis Microsoft PowerPoint terhadap Hasil Belajar Siswa IPA VIII MTs Nurul Falah NW Lajut tahun pelajaran 2019/2020.

\section{METODE PENELITIAN}

Penelitian ini menggunakan pendekatan kuantitatif dan jenis penelitian menggunakan metode eksperimen semu (quasi experimental). Pengumpulan data dengan menggunakan instrumen berupa tes, dokumentasi, dan observasi. Desain penelitian yang digunakan adalah post test only control design. Populasi dalam penelitian ini adalah seluruh siswa kelas VIII MTs Nurul Falah NW Lajut tahun pelajaran 2019/2020. Sampel dalam penelitian ini adalah seluruh siswa kelas VIII yaitu kelas VIII A berjumlah 25 siswa yang menjadi kelas kontrol dan kelas VIII B yang berjumlah 25 siswa yang menjadi kelas eksperimen sehingga berjumlah 50 siswa. Pemilihan sampel menggunakan teknik Simple Random Sampling, Variabel bebas adalah penggunaan media pembelajaran berupa multimedia interaktif menggunakan Microsoft Power Point sedangkan variabel terikat adalah hasil belajar siswa. Pengujian hipotesis terhadap variabel terikat menggunakan uji-t dengan aplikasi SPSS versi 22.0 for windows. Desain dalam penelitian ini dapat dilihat pada Tabel 1 .

Tabel 1. Desain Penelitian

\begin{tabular}{|c|c|c|c|}
\hline Kelompok & Pre-test & Perlakulan & Post-test \\
\hline$E$ & $O_{l}$ & $X_{l}$ & $0 ?$ \\
$K$ & $0_{l}$ & $X_{l}$ & $0 ?$ \\
\hline
\end{tabular}

(Sumber: Sugiyono, 2009)

Keterangan:

E : Kelompok Eksperimen

K : Kelompok Kontrol

$\mathrm{X}_{1}$ : Penerapan MMI berbasis Microsoft PowerPoint

$\mathrm{X}_{2}$ : Penerapan model konvensional

$\mathrm{O}_{1}$ : Tes Awal (Pre-test)

$\mathrm{O}_{2}$ : Tes Akhir (Post-test) 


\section{HASIL PENELITIAN DAN PEMBAHASAN}

Penelitian ini dilakukan pada kelas VIII dalam 3 (tiga) kali pertemuan dengan materi Sistem Pencernaan Manusia. Penelitian dilaksanakan di dua kelas menggunakan media pembelajaran yang berbeda, yaitu dengan menggunakan media pembelajaran multimedia berbasis Microsoft Power Point dan media konvensional. Hasil pengumpulan data dalam penelitian ini diperoleh dari tes yang diberikan kepada siswa kelas VIII B sebanyak 25 orang yang menggunakan media pembelajaran Microsoft PowerPoint (kelas eksperimen) dan siswa kelas VIII A sebanyak 25 orang yang menggunakan media pembelajaran berupa buku dan modul ( kelas kontrol). Data hasil penelitian sebagai berikut:

Tabel 2. Statistik Deskriptif Hasil Belajar Kelas Eksperimen dan Kelas Kontrol

\begin{tabular}{|c|c|c|c|c|c|}
\hline \multicolumn{2}{|c|}{ Kelas } & $\begin{array}{c}\text { Nilai } \\
\text { Min }\end{array}$ & $\begin{array}{c}\text { Nilai } \\
\text { Max }\end{array}$ & $\begin{array}{c}\text { Rata- } \\
\text { Rata }\end{array}$ & $\begin{array}{c}\text { Standar } \\
\text { Deviasi }\end{array}$ \\
\hline \multirow{2}{*}{ Eksperimen } & Pre-test & 32 & 72 & 53,52 & 13,09 \\
\cline { 2 - 6 } & Post-test & 57 & 94 & 79,92 & 10,51 \\
\hline \multirow{2}{*}{ Kontrol } & Pre-test & 35 & 75 & 51,64 & 12,63 \\
\cline { 2 - 6 } & Post-test & 47 & 92 & 69,56 & 12,29 \\
\hline
\end{tabular}

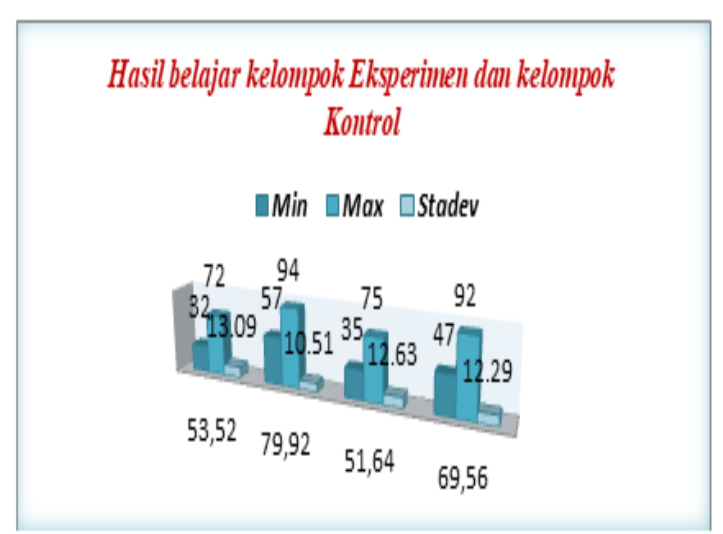

\section{Gambar 1. Diagram Hasil Belajar Kelas Eksperimen dan Kelas Kontrol}

Hasil belajar adalah suatu bukti keberhasilan seseorang dalam materi pelajaran yang dinyatakan dalam perubahan tingkah laku atau nilai yang diperoleh dari pengukuran berupa tes. Berdasarkan Tabel 2 dan Gambar 1, hasil tes kelas eksperimen dengan penerapan media Microsoft PowerPoint memperoleh nilai terendah 57 dan nilai tertinggi 94 , sehingga nilai rata-rata 79,92 serta standar deviasi 10,51, sedangkan untuk kelas kontrol dengan penerapan media konvensional diketahui nilai terendah 47 , nilai tertinggi 92 sehingga nilai rata-rata 69,56 dan standar deviasi 12,29. Berdasarkan perbandingan data hasil dari kedua kelas tersebut menunjukkan bahwa kelas eksperimen setelah diberikan materi menggunakan media microsoft power point mengalami peningkatan hasil belajar. Penggunaan multimedia interaktif berbasis Microsoft Power Point memberikan perubahan kepada siswa, sesuai dengan penelitian oleh Khaerunnisa, dkk (2018) bahwa media pembelajaran PowerPoint ini memberikan manfaat bagi siswa yaitu, mampu menciptakan suasana belajar kondusif dan menyenangkan, materi pembelajaran yang disampaikan lebih terlihat konkrit sehingga menarik perhatian siswa dan siswa lebih terangsang untuk mengetahui lebih jauh informasi tentang bahan ajar yang tersaji. Presentasi dengan microsoft Power Point merupakan salah satu cara yang digunakan untuk memperkenalkan atau menjelaskan sesuatu yang dirangkum dan dikemas ke dalam beberapa slide yang menarik. Hal tersebut bertujuan untuk mempermudah memahami penjelasan melalui visualisasi yang terangkum dalam slide teks, gambar atau grafik, suara, video, dan lain sebagainya.

Untuk mengetahui hipotesis yang diajukan diterima atau ditolak maka data dianalisis dengan Uji-t, ini berguna untuk menentukan ada tidaknya pengaruh media pembelajaran berbasis Microsoft Power Point terhadap hasil belajar siswa. Hasil analisis diperoleh melalui penggunaan aplikasi SPSS versi 22.0 for windows. Berdasarkan hasil uji hipotesis dengan uji $\mathrm{t}$ diperoleh nilai yaitu $\mathrm{t}_{\text {hitung }}=3,147$ sedangkan $\mathrm{t}_{\text {tabel }}=1,677$, artinya $t_{\text {hitung }}>t_{\text {tabel }}$ dengan taraf signifikansi sebesar 0.05 artinya $\mathrm{H}_{\mathrm{O}}$ di tolak dan $\mathrm{Ha}$ di terima. Berdasarkan data hasil uji hipotesis tersebut, maka terdapat pengaruh penggunaan multimedia interaktif berbasis Microsoft Power Point yaitu dapat meningkatkan hasil belajar siswa IPA kelas VIII MTs Nurul Falah NW Lajut tahun pelajaran 2019/2020.

\section{SIMPULAN}

Berdasarkan hasil penelitian bahwa nilai rata-rata kelas eksperimen yang 
menggunakan media Microsoft Power Point sebesar 79,92 sedangkan kelas kontrol yang menggunakan media konvensional sebesar 69,56. Berdasarkan hasil uji hipotesis dengan uji $\mathrm{t}$ diperoleh nilai yaitu $\mathrm{t}_{\text {hitung }}=3,147$ sedangkan $t_{\text {tabel }}=1,677$, artinya $t_{\text {hitung }}>t_{\text {tabel }}$ dengan taraf signifikansi sebesar 0.05 sehingga $\mathrm{H}_{\mathrm{O}}$ di tolak dan $\mathrm{Ha}$ di terima. Dengan demikian, terdapat pengaruh penggunaan multimedia interaktif berbasis Microsoft Power Point yaitu dapat meningkatkan hasil belajar IPA siswa kelas VIII MTs Nurul Falah NW Lajut tahun pelajaran 2019/2020.

\section{DAFTAR PUSTAKA}

Arsyad, Azhar. 2011. Media pembelajaran. Jakarta: PT Raja Grafindo Persada.

Khaerunnisa, Febriana, dkk. 2018. Pengaruh Penggunaan Media Power Point Terhadap Minat Belajar Sejarah Siswa Kelas X SMA Negeri 1 Bumiayu Tahun Ajaran 2017/2018. Indonesian Journal of History Education. Vol 6, Januari 2018. Hal. 31-41. Diakses Tanggal, 15 September 2019.

Mulyasa. 2012. Manejemen Pendidikan karakter. Jakarta: Bumi Aksara.

Sudjana, N. 2014. Penilaian Hasil Proses Belajar Mengajar. Bandung: PT Remaja Rosdakarya

Sugiyono. 2009. Statistik untuk Penelitian. Bandung: Alfabeta 